\title{
Foucault's Overlooked Organisation: Revisiting his Critical Works
}

\section{Michela Betta}

To cite this article: Michela Betta (2015): Foucault's Overlooked Organisation: Revisiting his Critical Works, Culture, Theory and Critique, DOI: 10.1080/14735784.2015.1078252

To link to this article: http://dx.doi.org/10.1080/14735784.2015.1078252

曲 Published online: 01 Sep 2015.

Submit your article to this journal $\asymp$

Џ Article views: 59

Q View related articles $\longleftarrow$

View Crossmark data ¿ 


\title{
Foucault's Overlooked Organisation: Revisiting his Critical Works
}

\author{
Michela Betta
}

\begin{abstract}
In this essay I propose a new reading of Michel Foucault's main thesis about biopower and biopolitics. I argue that organisation represents the neglected key to Foucault's new conceptualisation of power as something that is less political and more organisational. This unique contribution was lost even on his closest interlocutors. Foucault's work on power had a strong influence on organisation and management theory but interestingly not for the reasons I am proposing. In fact, although theorists in management and organisation studies have emphasised power in relation to discipline, control and subjectivity they have overlooked the transformative meaning of Foucault's organisation. His work on biopolitics has attracted opposition, too, as evidenced by the controversy sparked by Giorgio Agamben about Foucault's biopolitics. From Agamben's critique, it appears that Foucault's notions of politics and power do not allow a deconstruction of the violence of the concentration camp. However, a critical reading of Primo Levi's biographical narratives reveals the camp as a place where the prisoners' ability to organise their daily lives secured survival. To make sense of Levi's revelation, I use John Dewey's notion of habits as forms of organisation and reconnect it to Foucault's organisation. A shared understanding of the objective conditions of human activity and experience highlights the similarities between Dewey's pragmatism and Foucault's pragmatic metaphysics. In the end, however, Foucault's metaphysical background has caught up with him, pushing him away from his own most radical proposal that organisation was the new form of power and the new substance of politics.
\end{abstract}

\section{Foucault's organisation as the new form of power and politics}

I propose to reflect on Foucault's work about power and politics anew. A crucial aspect of his work has surprisingly been overlooked, particularly in regard to the notion of organisation. My main objective is to show that Foucault advanced a notion of power that took the form of organisation. Throughout his work, organisation is presented as something that makes power possible, not only in political but also in personal terms. Foucault's power is concrete action, cutting through, producing and establishing a variety of possible relations between individuals and between individuals and institutions. In the late 1970s, Foucault suggested that modern power needs bodies and 
population to exist, which is why he called modern power 'biopower' and its policies 'biopolitics'. To put individuals and population at the centre of modern political rationality, however, a transformation of political sovereignty was necessary. In this regard, Foucault argued that in order to include individuals and population productively in the political calculations of modern governments, new policies were required that aimed to enhance life through new scientific/medical and social practices. Such policies, or biopolitics, changed the way in which governed and governors interacted with each other and had the additional effect of overcoming the old sovereign state in favour of the government of the many (Foucault 2008). This is an apparently innocuous thesis that, however, contains the idea of the end of sovereignty and the diminishing role of the law. The inclusion of life in the calculations of power at the dawn of the eighteenth century, Foucault argued, marked modern governmentality (Foucault 1981, 1991, 2008). He described this passage from the classical age to modernity as a 'biological threshold of modernity' (seuil de modernité biologique), stating that 'for millennia, man remained what he was for Aristotle - a living animal with the additional capacity for a political existence - and that modern man is an animal whose politics places his existence as a living being in question' (1998: 143). Foucault also added that the new power and its biopolitics are characterised by individualising and totalising strategies targeting life and body (1981, 1983a), and finally, that biopolitics no longer works within the rationality of the law and rights but rather as an economic government that organises, manages and administers the life of individuals and of the population (2008).

Accordingly, power is not aligned with the law as a model: 'It is this image that we must break free of (qu'il faut s'affranchir), that is, of the theoretical privilege of law and sovereignty, if we wish to analyse power within the concrete and historical framework of its operation' (Foucault 1998: 90). With the rise of power against sovereignty, Foucault further suggested, the law becomes the norm and helps to normalise social and personal relationships rather than to discipline or regulate them. Under such conditions, power does not destroy life but administers it. A normalising society becomes the outcome of a technology of power that coheres around life because power is now 'organized around the management of life rather than the menace of death' (Foucault 1998: 147). Through taking care of life and the organisation of its (re)productive resources, power gains access to the body, opening up a completely new field of action and conduct. Foucault (2007) pointed to a new economy of conduct where one is conducted and conducts oneself at the physical level of body and life. The prefix 'bio' that Foucault attached to politics and power underlines this new taking care of life. It is new because it is driven by an economic perspective of productive meaning, and because power and politics now aim to organise life. Hence, we should not be too concerned with this prefix because Foucault neither used physical science to strengthen his case, nor privileged biological thinking. The 'bio' describes the content of politics and power in a changed epistemic configuration that he described as the power-knowledge nexus related to government and conduct. Because of this, however, Foucault's contemporary scholars have focused too much on trying to shed light on this nexus, and by so doing have lost sight of his more 
productive thesis at the level of the emerging new form of power. This new form is characterised by organisation.

It has certainly not been easy to position Foucault's work, especially for his contemporaries. But although many did not understand Foucault's new methods, they clearly saw the 're-orienting task of Foucault's work' (Said 1972) and the profound effects he had on traditional methods and analyses (Deleuze 1988; Veyne 1978, 1997). Barthes (1972) was one of the first theorists to realise that Foucault represented a shake-up of the intellectual establishment of the 1960s and 1970s by observing 'here is a first shock to our intellectual habits' (1972: 24) or, as Said (1972: 7) called them, 'habits of thought'. It was especially Foucault's wide-ranging analyses that, according to Smart (1994b, 1995b), caught the traditional intellectual scene unprepared. Many found that his work 'did not fit easily within existing disciplinary categories' while at the same time it had a 'significant impact within a number of fields of inquiry, ranging from philosophy, history, sociology, and political science to literary and cultural studies' (Smart 1994b: 1). Smart took upon himself the task of collecting all contributions related to Foucault published between 1960 and 1992. The amount of material collected led to the publication of seven edited volumes under the overarching title Michel Foucault, Critical Assessments (Smart 1994a, 1995a). From this collection of works about Foucault, it appears that almost every author commented extensively on what Foucault had written, often very minutely reconstructing his methodologies, assumptions and arguments. Intense scrutiny seems to have been applied in an attempt to reconnect to the old truths that Foucault had challenged or thrown out, rather than to embrace the new content emerging from his analyses. Commenting on this attempt to keep him within a traditional understanding of reason, Clavel (1994) observed that many tried in vain to glue back together what Foucault's analyses had torn apart, namely the consciousness of continuities, and by so doing they often missed the novelty of his work (see also Sloterdijk 2010).

Foucault's language might have played a role in how he was received. It was a new language that used the archaeological method to free, to unveil, what past analyses had covered up. Deleuze (1992) made an interesting observation in regard to Foucault's language by declaring it to have 'an oriental feel to it' (1992: 168), probably wanting to highlight by this his attention to detail. And yet the space carved by this language is not small, neither is it neutral. As declared a few years earlier by Said (1972: 27), in Foucault's writing, the events and people of the past return as 'postmodern denizens of a wide space that is generously impersonal, intellectually comprehended for all its discontinuities, and far from being an unheroic field of verbal action'. This is why, according to Bouchindhomme (1992), it is impossible to expect his language to represent just one global view, or his style to have just one dimension, which is why Veyne (2010: 2) called him a sceptical 'dual being'.

In Volume 1 of The History of Sexuality (HS1) (1998), Foucault developed an extraordinary language to capture the move toward life and the new substance of politics. He spoke of 'institutional crystallization embodied in state apparatus' (1998: 93), power passing through 'apparatus and institutions, without being exactly localized in them' (1998: 96), 'life-administering power' (1998: 136), 'managers of life and survival, of bodies and the race' (1998: 137), 
'administering life' (1998: 139), 'the organisation of power over life' (1998: 139), 'the administration of bodies and the calculated management of life' (1998: 140), 'the administration of collective bodies' (1998: 141), 'the distributive management of [the body's] forces (1998: 141), 'the management of life rather than the menace of death' (1998: 147), 'the organizing principle of two cultural forms' (1998: 148), the 'administration of sex' (1998: 148), 'controlling and administering the everyday life of sexuality' (1998: 150), and 'the organisation of "erotic zones" in the social body' (1998: 151). This new language strongly revealed an understanding of power and institutional authority as things that are embedded in administration and management as things that do not repress but enhance life. In HS1, Foucault took pains to show the effects of the repression hypothesis. As Dreyfus and Rabinow (1983: 131) stated, he masterfully unmasked it as 'a deception to be revealed'. The repression hypothesis is formed by several constitutive elements that are engaged in an incessant interplay between truth and power, where to speak the truth does not mean to be against power but rather to enhance it. In HS1, however, Foucault was interested in tracing back the historical conditions that led to the repression hypothesis by recasting it as a political technology that he called bio-power. He then suggested that bio-power marked a shift in the way governmentality operated that, however, remained invisible because of the effects of traditional theories of sovereignty that regarded power as a 'juridico-discursive' technology (Foucault 1998: 82).

Because Foucault's line of reasoning is well known, I shall not dwell on it here, focusing instead on the implications of his thesis. It seems that in Foucault's thinking, biopower is primarily an organisation that was cast as administration, apparatus, and order. According to Dreyfus and Rabinow (1983: xxvii), Foucault's overall original contribution was his 'pointing to agreed-upon examples of how a domain of human activity should be organized'. Foucault understood bio-power to be a 'pervasive organisation of our society', 'with no one directing it and everyone increasingly enmeshed in it, whose only end is the increase of power and order itself' (Dreyfus and Rabinow 1983: xxvi). Especially, the expression 'the administration of' recurs in almost all of Foucault's works, and it is an expression that has become very popular with many of Foucault's scholars. The meaning of these 'words as essences' (Said 1972: 7) did alert his interpreters. Dreyfus and Rabinow (1983) captured the meaning of Foucault's new conception of politics and power when they argued that, for Foucault, bio-politics focused on the body 'as the place in which the most minute and local social practices are linked up with the large scale organisation of power' (xxvi). Earlier, commenting on the ontological approach opened up by Foucault's analyses, Deleuze (1988) observed that through Foucault's work it appears that 'man exists only through the dissemination of various methods for organizing life' (130). Further reflecting on Foucault's notion of discourse, Deleuze argued that discourse shows how power 'organizes matters; or it forms or finalizes functions and gives them aims' (1988: 33). Gordon (1990: 11) saw discourse as 'the social organisation of subjectivity' through which power becomes an organising and ordering principle (Gordon 1991; see also Smart 1995a). As noted by Davidson (1997: 7) Foucault's discursive method brought to light the conditions that had historically and socially formed things and language. 
Veyne (2010: 119) tells us that Foucault thought that those conditions could be unmade if one knew how they were made.

Despite the acute sensibility of these interpreters, I believe that they have underestimated the real meaning of Foucault's work in relation to power and politics. They seem to assume that power puts organisation in place instead of the other way around, where organisation is that which makes power function. Like many others, they, too, remained caught up in the tradition of power and politics, and, as the previous citations suggest, they seem to believe that Foucault was only pointing to an operative change in the way in which politics and power acted on things and people. But if this were the case, Foucault would have added very little to philosophy and social science. It is when organisation becomes the new form of power, and organising becomes the new substance of politics, that different thinking becomes possible. Here lies Foucault's main contribution. That contribution has been overlooked, and the oversight has made Foucault's work appear to be solely concerned with a critical reformulation of old political thinking rather than with its complete rewriting.

The effects of Foucault's work on the scholars of the late 1990s and early 2000s were not noticeably different from those of the previous decades. His work on power became very important, particularly within the discipline of management and organisation studies. But as it appears in the writing of Fleming and Spicer (2014), in those years power was perceived within these disciplines as something that made the modern organisation possible. Now not even this seems to be the case anymore: 'We predict that the shifting nature of economic life currently defining large swathes of society will lead researchers to focus not so much on organisation per se but financialization' (2014: 286). Organisation still remains misunderstood. Foucault's idea that power relations are organised around social practices, that they are more ubiquitous than vertical, did not really have any impact on these disciplines. In other words, although power was now acknowledged to be less top-down, it remained/remains repressive, or controlling. The only addition was that repression was now circular rather than vertical. Social theorists and political philosophers also struggled with a more productive integration of Foucault's notion of organisation as the new form of power; it would have required some changes in the way social activity was articulated in relation to political repression and economic exploitation.

In the next section of this essay, I deal with these interpretations and critiques by also highlighting their shortcomings. I single out Agamben's critique because it most clearly shows how difficult it is to break out of established theories. In the following section, I address Agamben's critique. In doing so, I draw on Primo Levi, especially from his work about the concentration camp, and on John Dewey and his notions of habits. The reference to these two authors has an important double effect: Levi and Dewey highlight the importance of organisation for the individual and for social life, while, at the same time, their stories and analyses strengthen Foucault's idea of power as organisation. Through Levi's biographies it becomes apparent that survival in the camp was not a question of having the right consciousness but rather of having an innate or acquired ability to organise one's life under extreme conditions. Levi's work adds substance to Foucault's notion 
of power and freedom. Through Dewey it becomes possible to conceive of the camp as a form of over-organisation.

My reference to Dewey extends further than this. I noted earlier that Foucault's interpreters overlooked the consequences of his thesis concerning power as organisation. He might have contributed to this oversight in that Foucault himself provided little evidence to support his claims (I return to this issue later in the text). Dewey might help to overcome this shortcoming. In arguing that habits represent forms of organised social practices, namely social arrangements and interactions, he articulated something that was implicit in Foucault. When Foucault observed that power targets population, individuals and social relations, he certainly did not mean single individuals and bodies. Power can only target people's habits and social practices, and the mentality behind them. It is at this level that Dewey's work can be used productively to shed light on how power is organised around social relations. A comparison between Dewey and Foucault might surprise some. But as shown by Rorty (1982), these thinkers share an interest in objectivity and method. Rorty, however, is aware that methodological issues will not extend to philosophical views on life and ethics, and I agree with his conclusion that 'we should see Dewey and Foucault as differing not over a theoretical issue, but over what we may hope' (1982: 203). It is from this difference concerning hope that I draw my comparison between these two thinkers in the section entitled 'Dewey's pragmatism and Foucault's pragmatic metaphysics'. In the final section, 'What can we hope for?', I discuss the main issues raised in the essay and draw my conclusions.

I now turn to how, within management and organisation studies, as well as within social theory and political philosophy, too little attention has been given to Foucault's notion of organisation.

\section{Foucault's overlooked organisation}

Foucault had an enormous influence on management and organisation scholars. It is not possible to reconstruct the exegesis of Foucault's work within the discipline of management and organisation, and any bibliographic references can be but selective. However, it is obvious that Foucault's influence has played out in three major directions: power (and resistance) within the workplace (Burrell 1988; Clegg 1994; Clegg et al. 2006; Clegg and Haugaard 2009; Courpasson and Dany 2009; Fleming and Spicer 2007; 2014; Halford and Leonard 2005; Knights 1990; Newton 2004), discipline and control (Lounsbury and Ventresca 2003; McKinley and Taylor 1998; Savage 1998; Starkey and McKinlay 1998) and subjectivity and the self (Crane et al. 2009; Knights and Morgan 1991; Nahamas 1998; Randall and Munro 2010). In all these works, organisation is taken for granted inasmuch as it is understood as a given place, usually the workplace, where relationships unfold under the banner of control and repression. Foucault's idea that power and politics are no longer political but rather organisational does not find a productive resonance within this scholarly field that seems more influenced by old political thinking.

Munro (2012) has reconstructed Foucault's relevance within social science, particularly management and organisation studies, by accurately mapping out the various critical positions articulated within this field in 
regard to Foucault's work. Munro argues that there have been three interpretive variations in relation to Foucauldian biopolitics: advanced liberal governmentality, post-industrial mode of production and biocapitalist governmentality. Worth mentioning are also scholarly works on organisation as a process (Cooper 1990; Tsoukas and Chia 2003), where old notions of organisation are definitely questioned. Although promising, however, the idea of the process remains far too fluid to integrate Foucault's contribution productively, leaving the main question about the nature of organisation unaddressed. A question problematised by Holmes (1990) several years ago, and still unanswered, is, 'What do we, can we, understand by organisation? ... A term which can refer to a concentration camp, a car hire firm, the Lord's Day Observance Society or a Train Spotter' (1990: 198). But Munro is correct in insisting that organisation and management scholars have failed to elaborate on the new 'post-disciplinary forms of organisation of control' (Munro 2012: 359) anticipated by Foucault. If undertaken, such elaboration would probably shift the whole meaning of organisation within the field.

But if management and organisational scholars have failed to recognise the powerful implications of Foucault's organisation for their discipline, political philosophers and social scientists did not do better, and overlooked the economic methods and organisational content of post-political power. In this field, Foucault's work has been criticised for abandoning the safe routes of the rights discourse (McNay 2008, 2009; Myers 2008) in favour of a mentality of opportunities, for introducing an economic perspective into political thinking based on self-interest (Honnet 2004; Kalpagam 2000; Tribe 2009), and for not being critical enough of neo-liberalism and its notion of economic rationality shaping modern government (Lemke 2001) - hence Habermas (1981: 13) suggesting that Foucault was a young conservative. Although Foucault's work has been the object of extensive research in various fields and contexts for the past 50 years, Deutscher (2012) argues that within political philosophy and social theory such engagement with him has ultimately resulted in two distinctly separate hermeneutic analyses based on either life or sex. In her detailed essay on Volume 1 of the History of Sexuality, Deutscher (2012) argues that one of those who have emphasised life is Agamben. However, I believe that how he has done so must be evaluated, particularly in the light of his work on biopolitics and the camp. It is worth dwelling on Agamben's work because through the critique he articulates, Foucault's contribution to an understanding of organisation as the new form of power, and organising as the new content of politics, becomes even more evident.

Agamben (1998: 4) argued that Foucault's biopolitics cannot grasp 'the concentration camp and the structure of the great totalitarian state of the twentieth century'. ${ }^{1}$ Agamben charged Foucault with turning the link between individualising and totalising power into a 'blind spot'. Agamben's (1998: 6)

${ }^{1}$ But if Foucault was silent on the camp and the totalitarian state, it seems that Arendt did not capture the essence of the totalitarian state as inscribed in biopolitical sovereignty either. According to Agamben, the concentration camp does not represent, as Arendt suggests, 'human made hell' (Arendt 1994: 240), but rather the very opposite situation in which life becomes its trademark. 'Only because politics in our age had 
intention is to unveil the 'hidden point of intersection between the juridicoinstitutional and the biopolitical models of power'. ${ }^{2}$ The camp is understood by him to be a paradigm of neoliberal biopolitics. ${ }^{3}$ Contesting the Foucauldian idea that with the advent of modernity the law and legal discourse have lost their centrality, Agamben suggested that the law never stopped being at the centre of power. However, it does not work as a direct normalising tool, as was understood by Foucault, but rather through ban/abandonment. ${ }^{4}$ The ban, or abandonment, is the way by which, in order to keep its position and set the rule of privation, the law manages to apply itself by '(dis)applying itself' (Nancy 1993). According to Agamben, this move strengthens the relationship between law and life, but only in terms of subjugation: 'The force of law is that it holds life in its ban by abandoning it' (1998: 28-29). Abandoning is an act of violence that splits and bans forms of life deemed unworthy of legal protection from what is perceived and classified as good life (to be protected by the law). In speaking of the ban, Agamben suggests that targeted life is still part of the biopolitical discourse but as something that must be excluded. By incessantly reproducing the difference between good and bad life, biopolitical sovereignty creates a state of exception that allows it to ban with impunity (Agamben 2005). Drawing on Benjamin's (1996: 242, 243) idea that the exception has become the rule by becoming a law beyond itself, Agamben further noted that by being the 'pure space of exception' (1998: 134), the concentration camp represents the exception turned into norm. Agamben's critique requires some debating. Foucault did mention the menace of death that the Nazis brought about, but he regarded it as a case of extreme authority based on blood and race, the old politics that ruled with the law and the sword.

By speaking of the camp as a biopolitical paradigm, Agamben attempts to move the camp experience beyond its territorial limit by suggesting that it is a topographical and topological (spazio/soglia) space (see Giaccaria and Minca 2011). This move could be risky as it has the potential to undermine the meaning of the camp and create a dispersion of the experiences that have been captured by those who survived. Several authors have criticised

been entirely transformed into biopolitics was it possible for politics to be constituted as totalitarian politics to a degree hitherto unknown' (Agamben 1998: 120).

${ }^{2}$ Some questioned his critique, arguing that Agamben's reading of Foucault is structural rather than genealogical (Neal 2006).

${ }^{3}$ Agamben tends to lean toward Aristotle's notion of paradigm where the part of something (singularity) is analysed not in reference to a whole, or the whole in relation to the part - that is particular versus universal or universal versus particular - but rather the part is viewed as being concerned with the part. This means that the particular is understood in relation to the particular only. Such a move could neutralise the dichotomous thinking contained in the opposition particular-universal and the zone of undecidability that it creates. 'The paradigm is neither universal nor particular, neither general nor individual; it is a singularity which shows itself as such, and produces a new ontological context' (2002: 3).

${ }^{4}$ The notion of the ban was originally developed by Jean-Luc Nancy in his book The Birth to Presence (1993) that followed his highly controversial book The Inoperative Community (1991). 
Agamben's radical position because it seems to deny the possibility of resistance (Ek 2006: 369). His sovereign as solid and stable over the centuries has also been questioned (Long 2006; see also Ek 2006; Turner 2005), and some lament that he did not give any 'explanation for the sovereign's repeated victories and unstoppable march towards the camp' (Kalyvas 2005: 115). Finally, others have pointed out that a 'fundamentally passive subject does not exist' (Vardoulakis 2010: 153-154). It seems that Agamben does not pay close attention to how Foucault considered the case of consensus and violence, suggesting that consensus and violence 'do not constitute the principle or the basic nature of power' (Foucault 1983a: 220). Power, in his view, must always be understood as acting upon an acting subject, even in its extreme form when power constrains or forbids. There is a dramatic statement made by him in Omnes et Singulatim (1981) that sheds some light on this condition:

A man who is chained up and beaten is subject to force being exerted over him. Not power. But if he can be induced to speak, when his ultimate recourse could have been to hold his tongue, preferring death, then he has been caused to behave in a certain way. His freedom has been subjected to power. He has been submitted to government. If an individual can remain free, however little his freedom may be, power can subject him to government. (Foucault 1981: 253)

To Foucault there cannot be power without freedom because power is always exercised over free individuals. To explore the meaning of power and freedom in captivity we need to abandon the level of theoretical analysis and adopt a biographical approach that will help us understand some of the living conditions within the camp. To this purpose, I turn to Primo Levi. Through Levi it emerges that there is no deeper spatiality to be discovered in the camp, but evident, tangible, skin-deep experiences that need a biographical account to be captured. Levi has an extraordinary ability to identify structures and put people into them. He understands people's strengths and weaknesses, his included, because his observations are influenced by what might be called physical psychology. ${ }^{5}$ There is no morality blinding him, and there are no expectations of heroism.

Levi has an extraordinary ability to see people, relations and things as they are. This is why his accounts always evoke a sense of practical wisdom, increasing our understanding of the suffering of the human being in captivity as a physical and psychological dimension. At the same time, Levi can see beyond the sheer desperation and identify the instinct, the will to live. Levi's ability to capture what is at stake makes him write in a way that every sentence contains a story. Like a stonemason, he sculpts his words into his books, never taking decisions for us, always leaving us that

${ }^{5}$ In Mortal Questions (1979: 178) the moral philosopher Thomas Nagel mentioned the notion of physicalism pointing to the philosopher Donald Davidson's suggestion that a psychophysical theory could help elaborate on the physical causes and effects of mental events through physical descriptions. Such a theory has not been developed yet but neuroscience might be the next step to it. 
power or pain to draw conclusions. But he was not a sentimentalist; his pragmatism was beyond question. In his major opus, If This is a Man (also published under the title Survival in Auschwitz), Levi stated that everybody sooner or later in life discovers that perfect happiness is not possible, but that only a few ponder about the opposite consideration - that perfect unhappiness isn't possible either. Levi's instinctive rejection of any form of extreme advantageously positions him in the middle from where he can observe how prisoners organised their survival within a well-defined territory where human nature faced unprecedented challenges. Through their power to organise their survival, those prisoners effectively undermined biopolitical sovereignty. To understand this we must enter Levi's camp and trust his narrative, aware that personal experiences are like pain. They are something that 'cannot be denied and something that cannot be confirmed' (Scarry 1985: 13). This is a dilemma that we must navigate carefully.

\section{Survival in the camp as a matter of personal organisation}

Levi (1987) wrote one of the most dramatic reconstructions of life within a concentration camp, especially from the perspective of those who, like him, belonged to the saved and could therefore speak for those who 'drowned', thus becoming the 'witness and the archive' (Agamben 1999). But contrary to what Agamben does in Remnants of Auschwitz, where he logically reconstructs the legitimacy of remembrance and the validity of testimony, in this section I shall try to understand what and how or, better, through what conditions, a concentration camp can exist. In doing this, I rely on Primo Levi's books (1987, 1988). In If This Is a Man (1987) , Levi mentions one of the recurring sayings within Auschwitz: 'When things change they change for the worse' (1987: 122). Change came to disrupt the little organisation that the prisoners managed to build up individually in order to survive the systematic attempts to destroy life in general and Jewish life in particular. This nuanced differentiation between general and particular life is based on the distinctions existing in the camp that included prisoners of war, political prisoners, criminals and Jews (1988). ${ }^{6}$

The circumstances of the political prisoners were quite unique. First, as anti-fascists they were 'members of the secret defence organisation' (1988: 7) within the camp; secondly, they possessed a 'cultural background' that helped them to 'interpret' the events around them; thirdly, they had 'easy access to statistical data'; and finally, they held positions of power within the camp. Hence, the camp was a 'stratified microcosmos' (1988: 9) where there were invisible pockets of resistance that allowed some to survive and caused many others to die. Levi calls these 'grey zones'. The grey zone is driven by a 'network of human relations' (1988: 23) where the separation of good from

\footnotetext{
${ }^{6}$ This social hierarchy, however, did not suspend anti-Semitism in the camp. In more than one occasion, Levi showed that political prisoners were fighting the Nazi regime in political terms and totally disregarded the fate of the Jews. And ordinary criminals had even less scruples in this regard because many were fundamentally in agreement with the Nazis.
} 
evil, inside from outside, that many after the war tried to construe, was not possible. The camp management depended on destroying resistance by undermining any form of self-organisation - the 'political or moral armature' (1988: 25) that the prisoners had to have in order to resist destruction. The grey zone was made possible by protection and collaboration, and it both separated and joined the two camps populated by 'masters and servants' (1988: 27). Levi seems to suggest that survival was possible, although not guaranteed, by positioning oneself in the middle; those who could not do so, because they did not have the self-organisation that the camp violence required, drowned. These men were called within the camp the Muselmänner (Muselmann in the singular) ${ }^{7}$, an expression by which old prisoners named the weak, inept and those who were selected for execution (1987: 94). ${ }^{8}$ Levi reconstructs the profiles of four of the saved he met in Auschwitz (1987: 93-106). Theirs are dramatic stories. In spite of their differences, these four prisoners had something in common: they were great organisers, and through their ability to organise their personal lives and meagre possessions, their networks and connections, enemies and friends, they demonstrated the power to survive. The following four accounts are from Levi's book; I have condensed them.

Levi referred to a man called Schepschel. His ability to organise was exceptional. He was a man who had a prosperous business as a saddler before being transferred to the camp. Levi described him as neither 'robust, nor very courageous, nor very wicked'. He believed him to be not particularly astute, still deprived of a method that would have helped him to gain a little respite. But Schepschel had the skill to combine situations and occasions productively, and in doing so to innovate his own resources in an entrepreneurial bid to gain the maximum advantage. This was a strategy that helped him set aside a little bread that he used as capital to buy favours or buy/borrow tools to complete other more sophisticated little jobs that secured his position within the camp. Every opportunity was used to increase his capital even if this involved stealing. He was unscrupulous and, when the situation required it, he sacrificed his accomplice to gain favour in the eyes of the guards of the barrack block where he was confined to, and also save himself from being discovered and punished for stealing (Levi 1987: 98-99).

The second man was Alfred L. who to Levi embodied a technology of the self that allowed him to survive in the camp. This technology of the self was made of personal resources that took the form of 'a solid and fruitful

${ }^{7}$ Because of the lack of testimony and biographical accounts from female prisoners, we do not know how women selected for the final solution were referred to. Perhaps there was not such a term for them. This could be why the compound 'Mexico' located outside the perimeter of Birkenau's concentration camp, where only female prisoners transitioned, has never been mentioned in the literature (see Giaccaria and Minca 2011: 9).

${ }^{8}$ In my view, Levi's description of the Muselmann as the complete and true witness must be put into perspective. Levi was not theorising about the Muselmann. The description is based on real, physical experiences. Hence, I do not to agree with Davis' (2004: 88) conclusion that Agamben's philosophical closures have been influenced by Levi. To blame Levi for Agamben's own shortcomings is unfair. Vardoulakis (2010), too, disagreed with Agamben's representation of the Muselmann. 
"organisation"' through which he protected his person. He gained the reputation of a prominent person far before even becoming one through his face and hands always being clean. Alfred L. never compromised on cleanness, and by so doing he never bowed to the destructive discipline of the camp. This discipline took hold of people as soon they started losing respect for their own cleanliness. Alfred L. also managed to save bread from his own ration, 'so imposing upon himself a regime of supplementary privation'. He developed a mentality of the provision and 'carried it out with rigid inner discipline, without pity for himself or - with greater reason - for comrades who crossed his path' (Levi 1987: 99-101).

Levi's third man was Elias Lindzin, a man of short and strong build who distinguished himself for his versatility and ability to work across a range of professions without ever showing any fatigue and always entertaining others. His physical constitution allowed him to carry out jobs under which others collapsed and so he attracted the respect of the camp guards. 'His fame as an exceptional worker spread quite soon, and by the absurd law of the Lager [camp], from then on he practically ceased to work'. His physical indestructibility helped him to resist annihilation from within 'because he is insane'. Elias was 'a good worker and a good organiser' and his 'insanity and bestiality' turned him into a 'happy person' within the camp but, Levi remarked, he would probably not have been be as happy in a free society (Levi 1987: 101-104).

Finally there was Henri, the 'eminently civilised and sane' man with his excellent scientific and classical educational background. He had three theories for survival: 'organisation, pity and theft'. Through pity, 'if ably cultivated', one gets access to other people's feelings, even the 'primitive minds of the brutes' and becomes their friend and secrets keeper. Henri was exceptionally organised and could make productive use of the time that he spent with British POWs and other more prominent people; this allowed him to conduct 'traffic of products of English origin' that became his 'monopoly' which was 'all a matter of organisation'. His juvenile appearance evoked a sense of pity in others, and over time he learned how to use pity to secure protection. He made use of these strategies and acquired 'conspicuous friendships' that rarely forced him to use the third method, theft (Levi 1987: 104-106).

Levi's men opposed the violence that was inflicted upon them. They exercised their freedom in whatever form they could. The camp represented a world full of contradictions. In this respect, Levi stated that 'even the most perfect organisation has its flaws' (1988: 2). It seems that Levi saw the camp as an organisation that could be challenged by another organisation. He mentions that the political prisoners organised themselves as a form of internal resistance. But it was the bodies, habits and practices of the Jewish prisoners that engaged his mind in the camp and, later, his writing. It is through their forms of self-organisation that a response to the brutal sovereignty of the camp emerges as a powerful and painful reality. It is this physical reality and the embodiment of anti-organisation that is missing in Agamben's work, where we see different stages of lives but no bodies. At one stage, as if struck by a self-reflective impulse, Agamben wonders about the organisational form of its paradigm (1998: 122). Of interest here is his suggestion that the camp did not represent any economic advantage but rather an 
'organisational burden' (1998: 141). Levi tells us a different story. The camp constituted, especially during the last years of the war, 'an extensive and complex system which profoundly penetrated the daily life of the country' revealing how the camp was 'not a closed universe'. Rather, Levi saw that 'small and large industrial companies, agricultural combines, agencies and arms factories drew profits from the practically free labour supplied by the camps' where prisoners were 'exploited pitilessly and the inhuman conditions within the camp never questioned' (Levi 1988: 5).

From Primo Levi we have learned that life within a concentration camp was driven by a multiplicity of actors and events that went beyond the single-minded sovereignty of biopolitics. Life was alive in the actions and bodies of the prisoners and it remained so until the very end through organisation as a form of antisovereignty. We need to understand how this might have happened. Perhaps the actions of Levi's men can be described as resulting from habits and impulses. To explore this, I draw on the work of the American philosopher Dewey (1922). Dewey suggested that people's lives are determined by habits and that habits are organised activities (1922: 89). Society represents institutions and culture (its customs and practices), and this part of human life can under certain circumstances become 'over-organized' (1922: 103), particularly when habits become rigid and resist change. Over-organisation cannot be challenged by habits themselves. Only impulse can challenge and, by so doing, it reorganises habits. Dewey compared habit to an adult and impulse to a child - the first meaning settled experience, the latter fresh intelligence. The two are engaged in a struggle, but it is not 'civil warfare' (1922: 99). In extraordinary crises, impulses 'show by wild violent energy how superficial is the control of routine' (1922: 101), revealing an interesting relationship between impulse and habit. Impulse brings with itself the 'possibility but not the assurance of a steady reorganisation of habits to meet new elements in new situations' (1922: 104). Impulse is understood by Dewey to be a pivot of 're-adjustment, re-organisation' being as it is 'an indispensable source of liberation', a power insofar as it gives habits 'pertinence and freshness' (1922: 104-105).

To Dewey, freedom is facticity made of 'environment and human wants' (1922: 306-306). He acknowledged that there can be conflicts between 'freedom and organisation', but he further argued that the main problem lies 'not in organisation but in over-organisation' (1922: 306). He found it impossible to think of freedom without organisation: 'there is no effective or objective freedom without organisation' (1922: 306). Dewey was concerned with what he called 'the moral potentialities of physical science' (1922: 11) and worried about the general disregard that moral science shows toward human nature, perceived as something to be tamed because it is external to a self-fashioned, virtuous self. Dewey warned that 'there is no ready-made self behind activities', because active life results from 'complex, unstable, opposing attitudes, habits, impulses which gradually come to term with one another' (1922: 138). This is so because life is uninterrupted activity 'as long as it is life at all' (1922: 135). This activity is linked to the 'inconsistencies and shiftings in character' that one encounters in experience where 'the relative fluidity and diversity of the constituents of selfhood' (1922: 138) reveal the precariousness of a prefabricated morality and moral self. The self builds in and through activity, and conduct is where it manifests itself. It is also in 
this sense that Levi's biographical narratives become so important for the notion of organisation advanced within this article because they show how, through organising their everydayness, Levi's men acquired the power to resist. Levi reinforces the notion that people are always acting in the present and making sense of the present, no matter what physical and psychological threats they are subjected to. Levi's prisoners had habits that helped them to cope with their world; their habits resulted from a coalition of physical body, cognitive abilities and environment kept alive by hope.

To keep that cooperation working effectively, they had to organise their everyday perception and actions quite minutely. It was an act of 'skillful coping' (Dreyfus 2014). Dreyfus argues that 'we are always already in a world that is laid out in terms of our bodies and interests, and thus permeated by relevance' (2014: 106). That not many survived is not proof of their being powerless, but rather of the extreme hostility of the world in which they were living and with which they had to cope. I believe that this was Levi's sombre message. Under peaceful conditions, social life is shaped by shared experiences, social arrangements and interactions and the environment. Organisation under democratic conditions is less subjective as it relies more on habits and practices shared by people. Individuals are not able to change these habits and practices on their own. The process of change is always social and it involves communities and governments, power and politics, science and knowledge. If social conduct has to be changed, the process must involve discourse and policies. Dewey, like Foucault, was interested in conduct as something that has to do with people's behaviours. I explore this issue in the next section.

\section{Dewey's pragmatism and Foucault's pragmatic metaphysics}

Dewey's theory of conduct and social psychology is based on the assumption that body, experience and environment form a unity. This unity is represented by habits and its main characteristic is that it cannot be changed directly. To change habits it requires a 'congenial, antecedently prepared environment' (1922: 20). Social life forms through a productive and interdependent cooperation of humans and things. Dewy acutely distinguishes between materials, tools and proper means. Nails and boards, he argues, are materials for making a box. And a hammer and saw are tools. They all turn into means when they are 'brought in conjunction with eye, arm, and hand in some specific operation' (1922: 25). At the same time, eye, arm and hand, are appropriate means only when they are in action and cooperating with external materials and energies. Without an external support, the eye just stares and the hand just fumbles. Our bodily organs become means when they enter 'into organisation with things which independently accomplish definite results' - and according to Dewey 'these organisations are habits' (1922: 26). ${ }^{9}$ To change things we need means, and the means that, according to

\footnotetext{
${ }^{9}$ This discussion is reminiscent of Heidegger's notion of 'readiness-to-hand' and 'ready-to-hand' in Being and Time (1962). Dewey and Heidegger share the notion of experience and activity preceding thinking and reflection. It is impossible for me to
} 
Dewey, are closest to us, that are 'within our power', are habits (1922: 37). Every habit incorporates some part of the world, the objective environment, but no single habit, or group of habits, can incorporate 'the entire environment within itself or themselves' (1922: 51). At the same time, however, Dewey argued that the environment 'is many, not one' and that habits represent adjustment of environment and not just to it (1922: 53). Habits compete between and among each other, and they mutually modify each other, altering the unity that characterises them. This alteration is caused by impulses. Dewey regards impulses as fresh energy that enters an established organisation (habits) and its culture (customs), causing an unsettling of tradition and shared values. Conflicts between habits release impulsive activities that require an adjustment of habit, custom and convention (1922: 87). When impulse imposes itself deliberately against customs and habits, it signals the beginning of individuality (1922: 87).

This individuality challenges habits, namely organised activities. Dewey was interested in conduct and how organised activities, customs, and conventions undergo changes in interaction. He stated that in conduct what is secondary becomes primary. From the perspective of an individual, instinctive activity (impulse) comes first, but in human interactions (conduct) impulse becomes secondary: the newborn begins life as a baby dependent on adults with their formed habits (1922: 89). Hence, in conduct, impulses and instincts need habits to accomplish tasks, even when they appear to be the driving force of an individual. ${ }^{10}$ Thus, impulse in conduct represents a re-adjustment, a reorganisation, in habits. When this reorganisation brings freshness and pertinence to habit, impulse has liberated power (1922: 105). 'Impulses are the pivots upon which the re-organisation of activities turns, they are agencies of deviation, for giving new directions to old habits and changing their quality' (1922: 93). But it would be wrong if we were to think that Dewey, by arguing in favour of habits, was introducing a mechanistic understanding of human activity. 'Without habit there is only irritation and confused hesitation. With habit alone there is a machine-like repetition, a duplicating recurrence of old acts. With conflict of habits and release of impulse there is conscious search' (1922: 180). Dewey was interested in showing that individual freedom cannot materialise out of a solipsistic individual practising virtues and morality in isolation. Certainly, no one can deny that the individual is the bearer of experience and that human activity always implies

reconstruct this discussion in the present essay, but I have elaborated on their similarities and differences in my forthcoming book on Heidegger.

${ }^{10}$ Dewey did not differentiate between the two. This is because impulse alone evokes the idea of something that is loose, undirected. But in connection with human instinct it acquires a cultural meaning. He argued that animals live within a ready-made instinct, while human beings can adapt and change their instinct, and so by cutting across various activities their instincts become an activity that can be learned within an organised life. 'In learning habits it is possible for man to learn the habit of learning' (Dewey 1922: 105). I shall not enter into this discussion, confining myself to the comment that in the past 50 years a more sophisticated knowledge of how animals organise their safety, group life and reproduction has prompted some serious revision of our notion of animal instincts. 
interactions between individuals, and individuals and institutions. Interaction, however, is a form of coping with, and adjustment of and to, environments, and is always embedded in habits and social practices. Dewey provocatively states that 'It thinks' is a truer psychological statement than 'I think'.

The question is whether this it thinks can be reconciled with Foucault's subject. Foucault's subject, particularly in HS1, is a dual individual - at times weak and subservient to power relations, and at times strong and organising/shaping them. The idea of power through and in human activity represents Foucault's theoretical specificity. This specificity positions him between different traditions without making him actually embrace any. Dreyfus and Rabinow tried to capture Foucault's uncommitted position to established theoretical methodologies in the title of their 1983 book where Foucault is set beyond hermeneutics and structuralism. Discussing Foucault's power, Simons argued that it is difficult to locate Foucault on the political map we have inherited from the nineteenth century' (1995: 103). Hence, it becomes impossible to classify him in terms of oppositional or affirmative politics because doing so would undermine his whole idea of complexity (Simons 1995: 3). Olssen (1999), too, pondered over Foucault's methodological positioning. He accurately identified Foucault as a materialist, but not as 'a traditional' materialist because of his interest in the background beliefs that 'constitute experience' (Olssen 1999: 33).

Power, argued Foucault, as a concentrated or diffused form does not exist. It 'exists only when it is put into action' (1983a: 219). Power is a mode of action that does not work directly on others but acts upon their actions revealing 'an action upon an action, on existing actions or on those which may arise in the present or the future' (1983a: 220). Hence, the exercise of power 'consists in guiding the possibility of conduct and putting in order the possible outcome' (1983a: 221). This putting in order must be understood in terms of the organising form of power. Power is related to government as a way of organising the conduct of others. 'To govern, in this sense, is to structure the possible field or action of others' (1983a: 221). Here Foucault is still caught up in his old structuralist language, but what he really means is not structure but organisation as the new form of power and the new substance of politics. 'The exercise of power is not a naked fact, an institutional right, nor is it a structure which holds out or is smashed: it is elaborated, transformed, organised; it endows itself with processes which are more or less adjusted to the situation' (1983a: 224). Under such conditions, power relations 'have been progressively governmentalized, that is to say, elaborated, rationalised, and centralised in the form of, or under the auspices of, state institutions' (1983a: 224). Foucault captured these changes in the nature of power in his statement that power relations are 'both intentional and nonsubjective' (Foucault 1998: 94). This is the closest he came to Dewey's It thinks. And it is the furthest he moved from traditional political thinking.

It seems, however, that this idea of non-subjectivity gets lost in his subsequent works on ethics (1983b), and especially in History of Sexuality Volumes 2 and 3 . There he became more concerned with fears and the need to think individually and act collectively: 'My point is not that everything is bad, but that everything is dangerous ... If everything is dangerous, then 
we have something to do' (1983b: 231-232). The activism he is envisaging is rooted in an ethics driven by personal virtues and separate from other forms of social activity. Foucault wrote, 'I think we have to get rid of this idea of an analytical or necessary link between ethics and other social or economic or political structures' (1983b: 236). It is at this juncture that Foucault's pragmatism becomes metaphysical again, revealing his difficulty with completely leaving behind his past metaphysical position. It is this difficulty that was to make him 'abandon' (Donzelot 2008) the study of power and turn to ethics and the ethical self - a move that shifts him away from the pragmatism of the HS1, and from Dewey's It thinks, making him embrace notions of the self that unavoidably reinstate the (Kantian) subjective free will. Was this abandonment, or as some have described it a 'long detour' (Starkey and Hatchuel 2002), the result of a mistake that directed him toward new research focused on ethics rather than politics?

\section{What can we hope for? Discussion and conclusion}

I believe that Foucault, even when taking a strongly practical stand, underestimated how people's experiences and activities could also influence politics and power through their organisations, making him neglect how the institutions of a culture always articulate through organised habits and people's modes and moods and their shared social practices. In other words, he failed to consider that people and their practices embedded in a shared culture (customs) can also work on the institutions and influence their conduct (policies). As past politics and power needed disciplinary institutions to impose sovereignty, now power and politics need organisation to order, administer and manage the economy of life. But to elaborate on this important element, it would have required an analysis of events, human activities and experiences and that, at that time, was probably beyond Foucault's methodological capability. Instinctively, he turned his attention to micro phenomena such as practices and activities, the body and embodied experiences, selfknowledge and self-care. And this is, in my view, why he so strongly turned to a consideration of ethical practices, especially in his final years. Ethical practices might have appeared to him to be the sole practicable answer to a power that could productively organise individuals and their activities - shaping their subjectivity as a unilateral process. In the end, however, his attempts to reject old thinking and avoid a return to sovereignty might have taken up so much of his intellectual energy, particularly at the level of language, that it made him overlook the content of his organisation and the activities and experiences of those who are formed by it and who form it.

In spite of this, HS1 remains a strong book. Hence, Foucault himself might not have realised how deeply he was already cutting through traditional political thinking. According to Dreyfus and Rabinow, this 'increasing organisation of everything' as the 'central issue of our time' (1983: xxvi) remained empirically underdeveloped in HS1, making Foucault appear far too 'elusive'. The problem, however, is not one of will. It is not that Foucault did not want to explain organisation. The fact is that he could not explain what he had discovered. And this is a problem of methodology. Dreyfus and Rabinow (1983) see how Foucault's method did not allow him to elaborate 
on some of his central assumptions. They argue that the reason for the methodological impossibility lay in his theoretical background: 'He is so good at the history of systems of thought (practices), that he cannot deal with thoughts and practices when they are not systematically interrelated' (1983: 261).

Dreyfus and Rabinow somehow consider Foucault's problem to be an intrinsic limitation caused by a lack of understanding of everyday practices, of concrete social reality, but above all of physical reality at any given time (1983: 262). I see the acute sensibility of their conclusion, and partially agree with it. But perhaps there is more at stake. The notion of organisation moves us away from traditional thinking: the form of power has changed and so has the content of politics. Here clearly lies Foucault's incontestable creative and productive contribution. His metaphysical background, however, did not allow him to renounce the idea of the subject completely. 'My objective . . . has been to create a history of the different modes by which, in our culture, human beings are made subjects' (Foucault 1983a: 208). He seems to assume that critical subjects will be able to identify the identity imposed upon them and 'refuse what we are' (1983a: 216). Such a process of refusal, however, would necessitate a point of reference. To refuse what we have become we would have to know what lies ahead and consider it as superior, as the good subjectivity to be pursued. To know what lies ahead is not in our power unless we are able to identify the 'objective consequences' (Dewey 1922: 19) of present actions beyond all the contingencies and luck that might also play a role in how things ultimately turn out. This is not an impossible task, but it requires physical and psychological resources, and not just a solitary will to change. To argue in favour of a refusal of what one is, the metaphysical Foucault must assume that reason, virtues and deliberations will guide the search for a new, freer, better self. But Levi's accounts showed that physical action comes before moral reasoning. As Dewey stated, 'in case of a pinch, the mass prefer to be good fellows rather than to be good men' (1922: 5).

The problem is that we have to live with Foucault's legacy which, although difficult and at times elusive, still seems to offer a way out of its own limits. In fact, an increasing number of works embedded in empirical studies has demonstrated the potential of his language and ideas. Seen from this perspective, Dreyfus and Rabinow's fear that Foucault's work could risk becoming an historical gloss to archival research, that it could end up being 'incorporated into empirical historical procedures' (1983: 127), was perhaps too pessimistic. They keep lamenting that the lack of empirical proof has always been Foucault's major weakness: 'Foucault clearly owes us a more explicit account of how he is proceeding in many areas' (Dreyfus and Rabinow 1983: 127). But I think that this is an expectation that he could not satisfy methodologically at the time of his writing, and perhaps it was not his task to fill the gaps. Others are now doing exactly that. For example, Deutscher has taken great pains to show how, in HS1, reproduction is included through its exclusion: 'procreative sex plays no rhetorically decisive role in the work, yet as a preoccupation, it reproduces itself through the work' (Deutscher 2012: 131). Deutscher is left with very few hints from Foucault to substantiate her thesis about reproduction, and, although her line of reasoning is convincing, she is forced to admit that as 'small as it is, I draw attention to this 
intersection as the reproductive "hinge" in the work, a hinge which is not thematized' (2012: 124). In her interpretation of HS1, Deutscher is clearly influenced by Foucault's language and his recurring idea of the administration of confirming a trend toward the notion that reproductive sex must first of all be organised. Väliaho's work provides another example, especially where he points to the 'management of affectivity' and physiological forms of 'selforganisation' (2012: 65). Expressions such as 'the administration of' and 'the management of' recur several times not only in his works but also in other biopolitical works concerning affectivity and habits, seemingly giving further support to the proposition that currently taking care of life means nothing other than to organise the body and its organs, to manage life, to govern through a politics that is organisational first and foremost. As shown in the preceding discussion, Foucault's notion of power as organisation can help us read Levi's biographical accounts differently. It can help us conceive of habits and social practices as being more intentional than subjective, more organised than imposed. These are important achievements.

HS1 is Foucault's most courageous book. The same level of clarity of expression and intellectual independence does not occur in any of his other books. In HS1, Foucault challenged a whole intellectual tradition that conceived of power as being top-down and repressive. He threw a challenge to us by arguing that modern politics and power are economic in method and organisational in content - that organisation is the new form of power and the new substance of politics. It is now up to us to further explore the practical meaning of his ideas and pay due respect to his legacy.

\section{Disclosure statement}

No potential conflict of interest was reported by the authors.

\section{References}

Agamben, G. 1998. Homo Sacer: Sovereign Power and Bare Life. Translated by Daniel Heller-Roazen. Stanford, CA: Stanford University Press.

Agamben, G. 1999. Remnants of Auschwitz. The Witness and the Archive. Translated by Daniel Heller-Roazen. New York: Zone Books.

Agamben, G. 2002. What is a Paradigm? A Lecture by Giorgio Agamben. Available online http:/ / www.egs.edu./faculty/agamben/agamben-what-is-a-paradigm-2002.html (accessed 22 March 2012).

Agamben, G. 2005. State of Exception. Translated by Kevin Attell. Chicago, IL: University of Chicago Press.

Arendt, H. 1994. Essays in Understanding, 1930-1954. Edited by Jerome Kohn. New York: Harcourt \& Brace.

Barthes, R. 1972. 'Taking Sides'. In R. Barthes (ed), Critical Essays. Evanston, IL: Northwestern University Press, 163-170.

Benjamin, W. 1996. Selected Writings, Volume 1: 1913-1926. Edited by M. Bullock and M. W. Jennings, Cambridge, MA: Harvard University Press, 236-252.

Bouchindhomme, C. 1992. 'Foucault, Morality and Criticism'. In T. J. Armstrong (editor and translator). Michel Foucault Philosopher. London: Routledge, 309-321. 
Burrell, G. 1988. 'Modernism, Postmodernism and Organisational Analysis 2: The Contribution of Michel Foucault'. Organisation Studies 9:2, 221-235.

Clavel, M. 1994. 'Vivre autrement le temps' [Living differently over time]. Dits et Ecrits Vol III, no. 268. Paris: Gallimard.

Clegg, S. 1994. 'Weber and Foucault: Social Theory for the Study of Organisation'. Organisation 1:1, 149-178.

Clegg, S., Courpasson, D. and Phillips, N. 2006. Power and Organisations. Sage: London. Clegg, S. and Haugaard, M. 2009. The SAGE Handbook of Power. London: Sage.

Cooper, R. 1990. 'Organisation/Disorganisation'. In J. Hassard and D. Pym (eds), The Theory and Philosophy of Organisations. London: Routledge, 167-197.

Courpasson, D. and Dany, F. 2009. 'Cultures of Resistance in the Workplace'. In S. Clegg and M. Haugaard (eds), The SAGE Handbook of Power. London: Sage, 332-347.

Crane, A., Knights, D., Starkey, K., and Arnold D. G. 2009. 'The Conditions of Our Freedom: Foucault, Organisation, and Ethics'. Business Ethics Quarterly 18:3, 299-320.

Davidson, A. I. 1997. 'Structures and Strategies of Discourse: Remarks towards a History of Foucault's Philosophy of Language'. In A. I. Davidson (ed), Foucault and his Interlocutors. Chicago: The University of Chicago Press, 1-17.

Davis, C. 2004. 'Can the Dead Speak to Us? De Man, Levinas and Agamben'. Culture, Theory and Critique 45:1, 77-89.

Deleuze, G. 1992. 'What is a Dispositif?' In T. J. Armstrong (editor and translator). Michel Foucault Philosopher. London: Routledge, 159-168.

Deleuze, G. 1988. Foucault. Translated and edited by Seán Hand. London: The Athlone Press.

Deutscher, P. 2012. 'Foucault's History of Sexuality, Volume I'. Theory, Culture E Society 29:1, 119-137.

Donzelot, J. 2008. 'Michel Foucault and Liberal Intelligence'. Economy and Society 37:10, 115-134.

Dewey, J. 1922. Human Nature and Conduct: An Introduction to Social Psychology. London: George Allen and Unwin.

Dreyfus, H. L. 2014. Skillful Coping, Essays on the Phenomenology of Everyday Perception and Action. Edited by M. A. Wrathall. Oxford: Oxford University Press.

Dreyfus, H. L. and Rabinow, P. 1983. Michel Foucault: Beyond Structuralism and Hermeneutics. With an Afterword and an Interview with Michel Foucault. Second Edition. Chicago, IL: Chicago University Press.

Ek, R. 2006. 'Giorgio Agamben and the Spatialities of the Camp: An Introduction'. Swedish Society for Anthropology and Geography 88B:4, 363-386.

Fleming, P. and Spicer, A. 2007. Contesting the Corporation: Struggle, Power, and Resistance in Organisations. Cambridge, UK: Cambridge University Press.

Fleming, P. and Spicer, A. 2014. 'Power in management and organisation science'. The Academy of Management Annals 8:1, 237-298.

Foucault, M. 1981. Omnes et Singulatim: Towards a Criticism of Political Reason. The Tanner Lectures on Human Values at Stanford University. Cambridge, UK: Cambridge University Press.

Foucault, M. 1983a. 'The Subject and Power'. In H. L. Dreyfus and P. Rabinow (eds), Michel Foucault Beyond Structuralism and Hermeneutics. Chicago, IL: The University of Chicago Press, 208-226.

Foucault, M. 1983b. 'On the Genealogy of Ethics: An Overview of Work in Progress'. In H. L. Dreyfus and P. Rabinow (eds), Michel Foucault Beyond Structuralism and Hermeneutics. Chicago, IL: The University of Chicago Press, 229-264. 
Foucault, M. 1991. 'Governmentality'. In G. Burchell, C. Gordon and P. Miller (eds), The Foucault Effect. Studies in Governmentality. Chicago, IL: The University of Chicago Press, 87-104.

Foucault, M. 1998. The Will to Knowledge. The History of Sexuality 1. London: Penguin.

Foucault, M. 2007. Security, Territory, Population. Lectures at the College de France 1977-78. Translated by Graham Burchell. Edited by Michel Senellart. New York: Palgrave Macmillan.

Foucault, M. 2008. The Birth of Biopolitics. Lectures at the College de France 1978-79. Translated by Graham Burchell. Edited by Michel Senellart. New York: Palgrave Macmillan.

Giaccaria, P. and Minca, C. 2011. 'Topographies/topologies of the Camp: Auschwitz as a Spatial Threshold'. Political Geography 30:1, 3-12.

Gordon, C. 1990. 'Histoire de la Folie: An Unknown Book by Michel Foucault'. History of the Human Sciences 3:1, 3-26.

Gordon, C. 1991. 'Governmental Rationality: An Introduction'. In G. Burchell, C. Gordon and P. Miller (eds), The Foucault Effect, Studies in Governmentality. Chicago, IL: The University of Chicago Press, 1-51.

Habermas, J. 1981. 'Modernity Versus Postmodernity'. New German Critique 22:4, 3-14.

Halford, S. and Leonard, P. 2005. 'Place, Space and Time: Contextualizing Workplace Subjectivities'. Organisation Studies 27:5, 657-676.

Heidegger, M. 1962. Being and Time. New York: Harper.

Holmes, R. 1990. 'Persons, Role and Organisation: Some Constructivist Notes'. In J. Hassard and D. Pym (eds), The Theory and Philosophy of Organisations. London: Routledge, 198-218.

Honnet, A. 2004. 'Organized Self-Realization: Some Paradoxes of Individualization'. European Journal of Social Theory 7:4, 463-478.

Kalpagam, U. 2000. 'Colonial Governmenality and the Economy'. Economy and Society 29:3, 418-438.

Kalyvas, A. 2005. 'The Sovereign Weaver: Beyond the Camp'. In A. Norris (ed), Politics, Metaphysics, and Death: Essays on Giorgio Agamben's Homo Sacer. Durham, NC: Duke University Press, 107-134.

Knights, D. 1990. 'Subjectivity, Power and the Labour Process'. In D. Knights and H. Willmott (eds), Labour Process Theory. London: Macmillan, 297-335.

Knights, D. and Morgan, G. 1991. 'Corporate Strategy, Organisations, and Subjectivity: A Critique'. Organisation Studies 12:2, 251-273.

Lemke, T. 2001. 'The Birth of Biopolitics: Michel Foucault's Lectures at the College de France on Neo-liberal Governmentality'. Economy and Society 30:2, 190-207.

Levi, P. 1987. If this is a Man and The Truce. London: Abacus.

Levi, P. 1988. The Drowned and the Saved. London: Michael Joseph.

Long, J. C. 2006. 'Border Anxiety in Palestine-Israel'. Antipode 38:1, 107-127.

Lounsbury, M. and Ventresca, M. 2003. 'The New Structuralism in Organisation Theory'. Organisation 10:3, 457-480.

McKinley, A. and Taylor, P. 1998. 'Through the Looking Glass: Foucault and the Politics of Production'. In A. McKinley and K. Starkey (eds), Foucault, Management and Organisation Theory. London: Sage, 173-190.

McNay, L. 2008. Against Recognition. Cambridge: Polity Press.

McNay, L. 2009. 'Self as Enterprise: Dilemmas of Control and Resistance in Foucault's The Birth of Biopolitics'. Theory, Culture $\mathcal{E}$ Society 26:6, 55-77.

Munro, I. 2012. 'The Management of Circulation: Biopolitical Variations after Foucault'. International Journal of Management Review 14, 345-362.

Myers, E. 2008. 'Resisting Foucauldian Ethics: Associative Politics and the Limits of the Care of the Self'. Contemporary Political Theory 7, 125-146. 
Nagel, T. 1979. Mortal Questions. Cambridge, UK: Cambridge University Press.

Nahamas, A. 1998. The Art of Living: Socratic Reflections from Plato to Foucault. Berkeley, CA: University of California Press.

Nancy, J. L. 1991. The Inoperative Community. Minneapolis, MN: University of Minnesota Press.

Nancy, J. L. 1993. The Birth to Presence. Stanford, CA: Stanford University Press.

Neal, A. W. 2006. 'Foucault in Guantánamo: Towards an Archaeology of the Exception'. Security Dialogue 37:1, 31-46.

Newton, T. 2004. 'From Freemason to the Employee: Organisation. History and Subjectivity'. Organisation Studies 25:8, 1363-1387.

Olssen, M. 1999. Michel Foucault: Materialism and Education, Westport, CT: Bergin \& Garvey.

Randall, J. and Munro, I. 2010. 'Foucault's Care of the Self: A Case from Mental Health Work'. Organisation Studies, 31:11, 1485-1504.

Rorty, R. 1982. Consequences of Pragmatism, Essays, 1972-1980. Minneapolis, MN: University of Minnesota Press.

Said, E. W. 1972. 'Michel Foucault as an Intellectual Imagination'. Boundary 1:1, 1-36.

Savage, M. 1998. 'Discipline, Surveillance and the "Career": Employment on the Great Western Railway 1833-1914'. In A. McKinley and K. Starkey (eds), Foucault, Management and Organisation Theory. London: Sage, 65-92.

Scarry, E. 1985. The Body in Pain: The Making and Unmaking of the World. Oxford: Oxford University Press.

Simons, J. 1995. Foucault and the Political. London: Routledge.

Sloterdijk, P. 2010. Philosophische Temperamente. München: Diederichs.

Smart, B. (ed) 1994a. Michel Foucault, Critical Assessment. 1-3 volumes. London: Routledge.

Smart, B. (ed) 1994b. 'Introductory Essay: Situating Foucault'. In B. Smart (ed), Michel Foucault - Critical Assessments. 1 volume. London: Routledge.

Smart, B. (ed) 1995a. Michel Foucault - Critical Assessments. 4-7 volumes. London: Routledge.

Smart, B. 1995b. 'Introductory Essay: The Government of Conduct - Foucault on Rationality, Power and Subjectivity'. In B. Smart (ed), Michel Foucault Critical Assessments. 4 volume. London: Routledge.

Starkey, K. and Hatchuel, A. 2002. 'The Long Detour: Foucault's History of Desire and Pleasure'. Organisation 9:4, 641-656.

Starkey, K. and McKinlay, A. 1998. 'Afterword: Deconstructing Organisation - Discipline and Desire'. In A. McKinley and K. Starkey (eds), Foucault, Management and Organisation Theory. London: Sage, 230-241.

Tribe, K. 2009. 'The Political Economy of Modernity: Foucault's College de France lectures of 1978 and 1979'. Economy and Society, 38:4, 679-698.

Tsoukas, H. and Chia, R. 2003. 'On Organisational Becoming: Rethinking Organisational Change'. Organisation Science 13:5, 567-582.

Turner, C. 2005. 'Scenographies of Suicide: Hitler and His Victims'. Economy and Society $34: 2,261-279$.

Väliaho, P. 2012. 'Affectivity, Biopolitics and the Virtual Reality of War'. Theory, Culture E Society 29:2, 63-83.

Vardoulakis, D. 2010. 'The Ends of Stasis: Spinoza as a Reader of Agamben'. Culture, Theory and Critique 51:2, 145-156.

Veyne, P. 1978. Foucault Révolutienne l' Histoire. Paris: Édition du Seuil.

Veyne, P. 1997. 'Foucault Revolutionizes History'. In A. I. Davidson (ed), Foucault and His Interlocutors. Translated by Catherine Porter. Chicago: University of Chicago Press, 146-182.

Veyne, P. 2010. Foucault, His Thoughts, His Character. Translated by Janet Lloyd. Cambridge, UK: Polity Press. 
Dr Michela Betta is a teacher, researcher, theorist and writer. She studied philosophy and social sciences in Milan and Frankfurt, and completed her doctorate at the Johann Wolfgang Goethe University of Frankfurt. She is currently concerned with questions pertaining to phenomenological approaches to organisation, management and leadership, ethical theory. She has published on a variety of topics in scholarly journals and books embedded in her research interests. Michela has also published three collections of short stories with the intention of disseminating theoretical knowledge through literary media. She writes in three languages (Italian, English and German), and has published on phenomenology, Foucault, discourse and power, ethics and science. Michela Betta works at Swinburne University of Technology, Melbourne, Australia. 